\title{
HUBUNGAN TINGKAT KECEMASAN DENGAN LAMA PERSALINAN KALA II PADA IBU BERSALIN DI RSIA ANUGERAH MEDICAL CENTER KOTA METRO
}

\author{
Yona Desni Sagita \\ Program Studi D4 Bidan Pendidik \\ Sekolah Tinggi Ilmu Kesehatan (STIKes) Aisyah Pringsewu Lampung \\ Email: yonayori1207@gmail.com
}

INFO ARTIKEL
Riwayat Artikel:
Diterima: 02-01-2018
Disetujui: 30-01-2018

Kata Kunci:

Tingkat kecemasan, Lama persalinan kala II

\begin{abstract}
ABSTRAK
Abstrak: Berdasarkan data WHO tahun 2015 Rasio kematian ibu (MMR) selama kehamilan dan melahirkan berkisar antara 102/100.000 Kelahiran Hidup. Berdasarkan SDKI Tahun 2013 bahwa Angka Kematian Ibu di Indonesia sebesar 359 per 100.000 kelahiran hidup. Provinsi Lampung memiliki 130 kasus kematian ibu pada saat hamil, melahirkan dan nifas. Studi pendahuluan di Ruang Bersalin RSIA Anugerah Medical Center Kota Metro tahun 2016 bulan November sebanyak 22 ibu dengan perpanjangan kala II. Tujuan penelitian ini untuk mengetahui hubungan tingkat kecemasan terhadap lama persalinan kala II pada ibu bersalin di RSIA Anugerah Medical Center Kota Metro Tahun 2017.Jenis penelitian kualitatif dengan desain analitik dan pendekatan cross sectional. Populasi pada penelitian ini adalah semua seluruh ibu bersalin di RSIA Anugerah Medical Center Kota Metro sebanyak 50 ibu, sedangkan sampel diambil dengan tehnik total sampling sebanyak 50 ibu. Analisis yang digunakan adalah univariat dengan distribusi frekuensi dan bivariat menggunakan uji chi square. Hasil penelitian diketahui bahwa tingkat kecemasan ibu bersalin sebagian besar dengan tingkat kecemasan sedang sebanyak 17 ibu (34\%). lama persalinan kala II yang tidak normal sebanyak 22 ibu (44\%). Ada hubungan antara tingkat kecemasan dengan lama persalinan kala II pada ibu bersalin dengan nilai $p$ value: 0,009 . Kesimpulan penelitian ada hubungan tingkat kecemasan terhadap lama persalinan kala II pada ibu bersalin di RSIA Anugerah Medical Center Kota Metro Tahun 2017, sehingga disarankan kepada tenaga kesehatan untuk meningkatkan berperan aktif dalam mengurangi tingkat kecemasan ibu selama proses persalinan karena berkaitan dengan gangguan pada proses persalinan.
\end{abstract}

\begin{abstract}
The maternal mortality ratio (MMR) during pregnancy and childbirth ranges based on WHO data 2015 estimated from 102 / 100,000 live births. IDHS in 2013 estimated that the Maternal Mortality Rate in Indonesia amounted to 359 per 100,000 live births. Lampung province has 130 cases of maternal mortality during pregnancy, childbirth and childbirth. Preliminary study at the Maternity Room of RSIA Anugerah Medical Center Metro City in 2016 November as many as 22 mothers with second stage extension. The purpose of this study to determine the relationship of anxiety level to the second stage of labor delivery to the maternal mother at RSIA Anugerah Medical Center Metro City Year 2017.This was a quantitative research, analytic survey design with cross sectional approach. The population was whole mother of maternity in RSIA Anugerah Medical Center Metro City that consisted of 50 mother, while sample taken with total sampling technique that consisted of 50 mother. The analysis used univariate with frequency distribution and bivariate using chi square test.The result showed frequency distribution of maternal anxiety level was mostly with moderate anxiety level of 17 mothers (34\%). An abnormal second stage of labor during childbirth was 22 mothers (44\%). There is no relationship between the level of anxiety with the duration of labor of stage // on maternal mothers with value $p$ value: 0.009 . Conclusion of research there is correlation of anxiety level to the duration of labor of second stage at mother of maternity in RSIA Anugerah Medical Center of Metro City Year 2017. The suggestion for to health worker to increase active role in reducing mother's anxiety level during delivery process because related to disruption at delivery process.
\end{abstract}




\section{A. LATAR BELAKANG}

Berdasarkan kesepakatan global dalam Sustainable Development Goals (SDG's) menegaskan bahwa pada tahun 2030 menurunkan Angka Kematian Ibu (AKI) hingga dibawah 70 per 100.000 kelahiran hidup (Dirjen Bina Gizi KIA,2014). Pada target Milenium Development Goals (MDG's) pada tahun 2015 memiliki target penurunan angka kematian ibu sebesar 102 per 100.000 kelahiran hidup, namun pada pelaksanannya angka kematian ibu di Indonesia masih cenderung tinggi dan belum memenuhi target yang diinginkan. Berdasarkan laporan Survey Demografi Kesehatan Indonesia (SDKI) pada tahun 2012 sebanyak 359 per 100.000 kelahiran hidup (Profil Kesehatan Indonesia, 2015).

Data Dinas Kesehatan Provinsi Lampung tahun 2014 menurut yang dirilis oleh Humas Dinkes Provinsi Lampung berdasarkan data yang dikumpulkan dari seluruh kabupaten kota di Provinsi Lampung adalah sebesar 130 kasus (Dinas Kesehatan Provinsi Lampung, 2014), termasuk kasus kematian pada saat hamil, melahirkan dan nifas, dimana kasus kematian ibu tersebut sebanyak 59,78\% terjadi pada saat persalinan, di Kabupaten Lampung Timur itu sendiri terdapat 14 kasus kematian ibu dan angka ini lebih besar jika dibandingkan, Kabupaten Pesawaran sebanyak 9 kasus kematian ibu dan Lampung Barat sebanyak 7 kasus kematian ibu. Data menunjukan bahwa penyebab kematian ibu disebabkan oleh eklamsi 59,33\%, perdarahan 40,23\%, infeksi 4,2\%, dan penyebab lainnya merupakan yang terbesar yaitu 75,42\% (Profil Kesehatan Lampung, 2012). Angka kasus kematian ibu melahirkan di Kota Metro pada tahun 2014 menututr Profil kesehatan Kota Metro diperkirakan sebesar 58,4 per 100.00o KH (Profil Kesehatan Kota Metro, 2015).

Secara global $80 \%$ kematian ibu disebabkan oleh faktor langsung seperti perdarahan, eklamsi, sepsis, hipertensi dalam kehamilan, komplikasi abortus dan partus macet atau persalinan lama. Persalinan macet atau partus lama merupakan penyumbang kematian ibu kisaran 8\% secara global. Persalinan lama maka akan mengacu pada durasi ataupun lamanya persalinan, lama persalinan pada ibu akan berbeda berdasarkan kondisi yang terjadi pada ibu bersalin. Sebagai contoh pada primigravida dan multigravida akan berbeda durasinya serta pda ibu yang megalami kondisi psikologis berbeda juga akan mengalami durasa lama persalinan yang berbeda pula (Mochtar, 2012).

Persalinan normal adalah merupakan persalinan yang berlangsung dengan kekuatan ibu sendiri tanpa bantuan alat serta tidak melukai ibu beserta janinnya. Kala II persalinan dimulai ketika dilatasi serviks sudah lengkap dan berakhir ketika janin sudah lahir. Tahapan atau kala dalam persalinan meliputi kala I (kala pembukaan), kala II (kala pengeluaran), kala III (kala uri), kala IV (kala observasi atau pengawasan). Pada primigravida kala II persalinan biasanya berlangsung $<1$ jam sedangkan pada multigravida biasanya berlangsung $<30$ menit. Faktor-faktor yang mempengaruhi persalinan antara lain tenaga atau kekuatan ibu (power), janin (passanger), jalan lahir (passage), kejiwaan (psyche) meliputi kecemasan. Kecemasan pada ibu bersalin akan mempengaruhi proses persalinan.

Pada setiap tahap kehamilan sampai dengan menjelang persalinan, selain perubahan fisik ibu juga akan mengalami perubahan psikologis, dimana ibu tersebut akan dituntut untuk beradaptasi pada setiap perubahan yang terjadi, dalam menjalani proses ini dukungan keluarga secara intensif dibutuhkan oleh ibu (Sulistyawati, 2012).

Suasana psikologis ibu yang tidak mendukung akan mempersulit proses persalinan. Kondisi cemas yang berlebihan, khawatir dan takut tanpa sebab, hingga akhirnya berujung pada stres. Kondisi stres inilah yang mengakibatkan otot tubuh menegang, terutama otototot yang berada di jalan lahir ikut menjadi kaku dan keras sehingga sulit mengembang sehingga mengganggu proses persalinan. Emosi yang tidak stabil juga akan membuat ibu merasakan sakit yang semakin hebat (Amalia, 2009).

Kondisi psikologis ibu akan sangat mempengaruhi perkembangan bayi dan juga mempengaruhi proses kelancaran dalam persalinan, ibu sangat membutuhkan dukungan dan ungkapan kasih terlebih dari orang terdekatnya terutama oleh suami. Keluarga terdekat ataupun suami diharapkan agar selalu memberikan dukungan dan kasih sayang kepada ibu (Sulistyawati, 2012).

Berdasarkan hasil prasurvey yang dilakukan di Ruang Bersalin Rumah Sakit Ibu dan Anak Anugerah Medical Center Kota Metro untuk data mengenai perpanjangan durasi persalinan berdasarkan catatan persalinan dalam partograf data 3 bulan terakhir tahun 2016 pada bulan September terdapat 14 ibu dengan perpanjangan kala II, bulan Oktober sebanyak 19 ibu dan pada bulan November sebanyak 22 ibu. Hal ini menunjukkan angka kejadian perpanjangan durasi persalinan kala II ada peningkatan setiap bulannya. Data ini lebih tinggi jika dibandingkan dengan RSB Asih Kota Metro dimana bulan Oktober sebanyak 9 ibu dan pada bulan November sebanyak 11 ibu mengalami perpanjangan durasi persalinan dalam kala II. Tujuan penelitian ini adalah untuk mengetahui tingkat kecemasan terhadap lama persalinan kala II pada ibu bersalin di RSIA Anugerah Medical Center Kota Metro.

Ruang lingkup penelitian ini meliputi metode penelitian yang digunakan adalah analitik. Jenis penelitian yang akan digunakan yaitu kuantitatif dengan rancangan cross sectional. Subjek penelitian adalah seluruh ibu bersalin normal, dan objek penelitian adalah tingkat kecemasan dan lama persalinan kala II, lokasi penelitian dilaksanakan di Rumah Sakit Ibu dan Anak Anugerah Medical Center Kota Metro dan dilaksanakan pada bulan April tahun 2017.

\section{B. KAJIAN TEORI}

\section{Kala Persalinan}

Persalinan adalah kejadian alami, meskipun disertai oleh pengejangan otot rahim dan rasa sakit yang dirasakan oleh ibu yang akan bersalin. Persalinan adalah proses pengeluaran hasil dari konsepsi yang viabel melalui jalan lahir (Mochtar, 2012). Persalinan adalah proses membuka dan menipisnya serviks, dan janin turun kedalam jalan lahir (Prawirohardjo,2010).Kala II persalinan dimulai ketika dilatasi serviks sudah lengkap dan berakhir ketika janin sudah lahir, kala II persalinan ini disebut juga stadium ekspulsi janin (Prawirohardjo, 2010).

\section{Tingkat Kecemasan}

Kecemasan adalah gangguan alam perasaan yang ditandai dengan perasaan ketakutan atau kekhawatiran 
yang mendalam dan berkelanjutan, tidak mengalami gangguan dalam menilai realitas, kepribadian masih tetap utuh, perilaku dapat terganggu tetapi masih dalam batas-batas normal (Hawari, 2011).Gangguan kecemasan umum akan menjadikan individu mengalami ketegangan yang berlebihan dalam menghadapi stres, disertai kekhawatiran yang terus-menerus terhadap segala macam masalah yang mungkin terjadi, serangan panik merupakan keadaan tiba-tiba yang penuh dengan keprihatinan serta merasa yakin bahwa sesuatu yang mengerikan akan terjadi (Stuart, 2012).Untuk mengetahui sejauh mana derajat kecemasan seseorang digunakan skala kecemasan yang menggunakan kuisioner guna memperoleh hasil yang benar-benar objektif dengan mengikuti petunjuk penskorannya.

\section{METODE PENELITIAN}

Jenis penelitian adalah analitik kuantitatif dengan rancangan cross sectional. Penelitian ini dimaksudkan untuk menganalisa ada tidaknya hubungan dan apabila ada, berapa eratnya hubungan serta berarti atau tidaknya hubungan tersebut.

Populasi dalam penelitian ini adalah keseluruhan ibu bersalin di RSIA Anugerah Medical Center Kota Metro. Berdasarkan hasil rata-rata persalinan untuk setiap bulannya diperkirakan jumlah ibu bersalin berjumlah 50 ibu bersalin setiap bulan. Sampel diambil dengan teknikaccidental samplingberjumlah 50 ibu bersalinAlat pengumpulan data dalam penelitian ini adalah lembar observasi penilaian tingkat kecemasan berupa kuisioner DASS (Depression Anxiety Stress Scale) dan lembar partograf untuk mengamati lama persalinan sampai pada kala II.

Analisis univariat menghasilkan distribusi frekuensi dan persentase dari tiap variabel. Analisis bivariat dilakukan menggunakan uji chi square

\section{HASIL}

TABEL 1

Distribusi frekuensi tingkat kecemasan ibu bersalin

\begin{tabular}{clcc}
\hline No. & $\begin{array}{c}\text { Tingkat } \\
\text { Kecemasan }\end{array}$ & Frekuensi & $\begin{array}{c}\text { Persentase } \\
\text { (\%) }\end{array}$ \\
\hline 1 & Normal & 13 & $\mathbf{2 6 \%}$ \\
2 & Ringan & 15 & $30 \%$ \\
3 & Sedang & 17 & $34 \%$ \\
4 & Berat & 4 & $8 \%$ \\
5 & Sangat Berat & $\mathbf{1}$ & $\mathbf{2 \%}$ \\
& Jumlah & $\mathbf{5 0}$ & $\mathbf{1 0 0}$ \\
\hline
\end{tabular}

Diketahui bahwa tingkat kecemasan dari 50 ibu bersalin di RSIA Anugerah Medical Center Kota dengan tingkat kecemasan normal sebanyak 13 ibu (26\%), kecemasan ringan sebanyak $15 \mathrm{ibu}$ (30\%), kecemasan sedang sebanyak 17 ibu (34\%), kecemasan berat sebanyak $4 \mathrm{ibu}$ (8\%), dan kecemasan sangat berat sebanyak 1 ibu (2\%).
TABEL 2

Distribusi distribusi frekuensi lama persalinan pada kala II ibu bersalin

\begin{tabular}{cccc}
\hline No. & $\begin{array}{c}\text { Lama } \\
\text { Persalinan } \\
\text { Kala II }\end{array}$ & Frekuensi & $\begin{array}{c}\text { Persentase } \\
\text { (\%) }\end{array}$ \\
\hline 1 & Normal & 28 & $56 \%$ \\
2 & Tidak normal & 22 & $44 \%$ \\
& JUMLAH & $\mathbf{5 0}$ & $\mathbf{1 0 0}$ \\
\hline
\end{tabular}

Diketahui bahwa lama persalinan pada kala II dari 50 ibu bersalin di RSIA Anugerah Medical Center Kota Metro sebagian besar dengan lama persalinan yang normal sebanyak 28 ibu (56\%) dan dengan lama persalinan kala II yang tidak normal sebanyak $22 \mathrm{ibu}$ (44\%).

TABEL 3

Hubungan tingkat kecemasan dengan lama persalinan kala II pada ibu bersalin

\begin{tabular}{|c|c|c|c|c|c|c|c|}
\hline \multirow{3}{*}{$\begin{array}{l}\text { Tingkat } \\
\text { Kecemasan }\end{array}$} & \multicolumn{4}{|c|}{ Lama Persalinan } & \multirow{2}{*}{\multicolumn{2}{|c|}{ Jumlah }} & \multirow{3}{*}{$\begin{array}{c}P \\
\text { value }\end{array}$} \\
\hline & \multicolumn{2}{|c|}{ Normal } & \multicolumn{2}{|c|}{$\begin{array}{c}\text { Tidak } \\
\text { Normal } \\
\end{array}$} & & & \\
\hline & $\mathrm{n}$ & $\%$ & $\mathrm{n}$ & $\%$ & $\mathrm{n}$ & $\%$ & \\
\hline Normal & 10 & 76,9 & 3 & 23,1 & 13 & 100 & \\
\hline Ringan & 12 & 80 & 3 & 20 & 15 & 100 & \\
\hline Sedang & 5 & 29,4 & 12 & 70,6 & 17 & 100 & \\
\hline Berat & 1 & 25 & 3 & 75 & 4 & 100 & 0,009 \\
\hline $\begin{array}{l}\text { Sangat } \\
\text { Berat }\end{array}$ & o & 8,3 & 1 & 91,7 & 1 & 100 & \\
\hline Jumlah & 28 & 56 & 22 & 44 & 50 & 100 & \\
\hline
\end{tabular}

Diperoleh hasil bahwa dari 13 ibu dengan tingkat kecemasan normal terdapat $10 \mathrm{ibu}(76,9 \%)$ dengan lama persalinan normal dan 3 ibu $(23,1 \%)$ dengan lama persalinan tidak normal, dari $15 \mathrm{ibu}$ dengan tingkat kecemasan ringan terdapat $12 \mathrm{ibu}(80 \%)$ dengan lama persalinan normal dan 3 ibu (20\%) dengan lama persalinan tidak normal, dari $17 \mathrm{ibu}$ dengan tingkat kecemasan sedang terdapat $5 \mathrm{ibu}(29,4 \%)$ dengan lama persalinan normal dan 12 ibu (70,6\%) dengan lama persalinan tidak normal, dari 4 ibu dengan tingkat kecemasan berat terdapat $1 \mathrm{ibu}$ (25\%) dengan lama persalinan normal dan 3 ibu (75\%) dengan lama persalinan tidak normal dan dari 1 ibu dengan kecemasan sangat berat dengan lama persalinan yang tidak normal. Hasil uji statistik chi square diperoleh nilai $\mathrm{p}$ value: $0,009<0,05$ artinya ada hubungan antara tingkat kecemasan dengan lama persalinan kala II pada ibu bersalin di RSIA Anugerah Medical Center Kota Metro tahun 2017.

\section{E. Pembahasan}

\section{Distribusi Frekuensi Tingkat Kecemasan}

Berdasarkan hasil analisa data dapat diketahui bahwa tingkat kecemasan ibu bersalin di RSIA Anugerah Medical Center Kota Metro dengan tingkat kecemasan normal sebanyak 13 ibu (26\%), kecemasan ringan sebanyak $15 \mathrm{ibu}$ (30\%), kecemasan sedang sebanyak 17 ibu (34\%), kecemasan berat sebanyak 4 ibu (8\%), dan kecemasan sangat berat sebanyak 1 ibu (2\%).

Tingkat kecemasan adalah gangguan alam perasaan yang ditandai dengan perasaan ketakutan atau 
kekhawatiran yang mendalam dan berkelanjutan, tidak mengalami gangguan dalam menilai realitas, kepribadian masih tetap utuh, perilaku dapat terganggu tetapi masih dalam batas-batas normal (Hawari, 2011). Gangguan kecemasan umum akan menjadikan ibu mengalami ketegangan dalam menghadapi persalinannya, disertai kekhawatiran yang terusmenerus terhadap segala macam masalah yang mungkin terjadi (Stuart, 2012).

Penilaian mengenai tingkat kecemasan ibu tersebut didasarkan terhadap penilaian dari tingkat kecemasan seperti membayangkan proses persalinan, frekuensi bertanya kepada orang lain bagaimana cara melahirkan, membayangkan sakitnya proses persalinan atau bertanya kepada orang lain mengenai sakitnya proses persalinan, kekhawatiran mengenai kondisi bayi, serta kekhawatiran untuk dapat melahirkan secara normal. Penilaian didasarkan terhadap frekuensi ibu seberapa sering ibu mengungkapkan kekhawatiran tersebut di mana pada ibu dengan tingkat kecemasan normal hanya menunjukkan beberapa indikator kekhawatiran saja, pada ibu dengan kecemasan ringan hanya sesekali mengungkapkan hal tersebut, ibu dengan kecemasan sedang juga mengungkatkan ekspesi kecemasan namun tidak terlalu sering, sedangkan pada ibu dengan kecemasan berat dan sangat berat frekuensi ungkapan dari kecemasan sering diajukan dan berulang-ulang sehingga ekspresi kecemasan semakin terlihat pada ibu saat mendekati proses persalinan.

Hasil penelitian ini memiliki kesamaan dengan penelitian yang dilakukan oleh Rahmi (2013) dengan judul Hubungan Tingkat Kecemasan Dengan Kelancaran Proses Persalinan Ibu Primigravida di Rumah Sakit Ibu dan Anak Banda Aceh Tahun 2013 dengan hasil penelitian untuk analisa univariat dari 36 responden 23 responden $(63,8 \%)$ yang mengalami kecemasan ringan dan tidak merasakan cemas.

Berdasarkan hasil tersebut penulis berasumsi bahwa tingkat kecemasan yang terjadi pada ibu bersalin merupakan hal yang umum terjadi karena ibu kekhawatiran terhadap segala macam masalah yang mungkin terjadi (Stuart, 2012). Berdasarkan hasil tersebut maka diperlukan konseling dari para tenaga kesehatan pada ibu menjelang persalinan guna mengurangi tingkat kecemasan ibu serta perlu adanya pendampingan dari anggota keluarga lain agar ibu lebih tenang dalam menjalani proses persalinan.

\section{Distribusi Lama Persalinan kala II}

Berdasarkan hasil analisa data dapat diketahui bahwa lama persalinan pada kala II ibu bersalin di RSIA Anugerah Medical Center Kota Metro sebagian besar dengan lama persalinan yang normal sebanyak $28 \mathrm{ibu}$ (56\%) dan dengan lama persalinan kala II yang tidak normal sebanyak 22 ibu (44\%).

Persalinan kala II merupakan kala pengeluaran janin, sewaktu uterus dengan kekuatan his yang bertambah untuk mendorong janin keluar (Mochtar, 2012). Kala II persalinan dimulai ketika dilatasi serviks sudah lengkap dan berakhir ketika janin sudah lahir, kala II persalinan ini disebut juga sebagai stadium ekspulsi janin (Prawirohardjo, 2010).

Hasil penelitian ini memiliki kesesuaian dengan penelitian yang dilakukan oleh Anggriani (2006) dengan judul Pengaruh kecemasan ibu hamil terhadap lama persalinan di RSUD Mataram Nusa Tenggara Barat dengan hasil analisa univariat terdapat $(50,75 \%)$ dengan persalinan kala II yang normal.

Berdasarkan hasil tersebut penulis berasumsi bahwa adanya ibu yang mengalami lama persalinan yang tidak normal tersebut dapat dimungkinkan karena ibu mengalami kecemasan akibat persiapan fisik untuk melahirkan, pengalaman persalinan, dukungan orang terdekat dan intregitas emosional serta faktor lain yang berhubungan dengan proses persalinan seperti kekuatan (power); his (kontraksi uterus), kontraksi otot dinding perut, kontraksi diafragma pelvis, ketegangan, kontraksi ligamentumrotundum, efektivitas kekuatan mendorong dan lama persalinan. Berdasarkan hal tersebut maka diperlukan konseling pada ibu selama kehamilan untuk mempersiapkan persalinannya dengan baik meliputi kesigapan fisik dan mental guna menjalani persalinan melalui pemeriksaan kehamilan yang rutin.

\section{Hubungan Tingkat Kecemasan dengan Lama Persalinan kala II}

Hasil uji statistik chi square diperoleh nilai $\mathrm{p}$ value: 0,009 < 0,05 artinya ada hubungan antara tingkat kecemasan dengan lama persalinan kala II pada ibu bersalin di RSIA Anugerah Medical Center Kota Metro tahun 2017.

Adanya hubungan antara tingkat kecemasan dengan lama persalinan kala II tersebut juga ditunjukkan dari hasil analisa dimana dari $13 \mathrm{ibu}$ dengan tingkat kecemasan normal terdapat 10 ibu $(76,9 \%)$ dengan lama persalinan normal dan 3 ibu $(23,1 \%)$ dengan lama persalinan tidak normal, dari $15 \mathrm{ibu}$ dengan tingkat kecemasan ringan terdapat $12 \mathrm{ibu}(80 \%)$ dengan lama persalinan normal dan 3 ibu (20\%) dengan lama persalinan tidak normal, dari $17 \mathrm{ibu}$ dengan tingkat kecemasan sedang terdapat $5 \mathrm{ibu}(29,4 \%)$ dengan lama persalinan normal dan 12 ibu $(70,6 \%)$ dengan lama persalinan tidak normal, dari 4 ibu dengan tingkat kecemasan berat terdapat $1 \mathrm{ibu}$ (25\%) dengan lama persalinan normal dan 3 ibu (75\%) dengan lama persalinan tidak normal dan dari 1 ibu dengan kecemasan sangat berat dengan lama persalinan yang tidak normal sehingga terlihat bahwa pada ibu dengan tingkat kecemasan sedang sampai dengan berat sebagian besar mengalami lama persalinan yang tidak normal.

Adanya hubungan antara tingkat kecemasan dengan lama persalinan kala II tersebut memiliki kesesuaian dengan teori yang menyebutkan bahwa lama persalinan salah satunya dipengaruhi oleh kondisi psikologis dari ibu yang mengakibatkan ibu mengalami gangguan alam perasaan yang ditandai dengan perasaan ketakutan atau kekhawatiran yang mendalam dan berkelanjutan, mengalami gangguan dalam menilai realitas, kepribadian masih tetap utuh, perilaku dapat terganggu (Hawari, 2011).

Gangguan kecemasan akan mempengaruhi proses persalinan ini karena hal tersebut akan menjadikan ibu mengalami ketegangan yang berlebihan dalam menghadapi proses persalinan, disertai kekhawatiran yang terus-menerus terhadap segala macam masalah yang mungkin terjadi, serangan panik merupakan keadaan tiba-tiba yang penuh dengan keprihatinan yang meluap-luap serta merasa yakin bahwa sesuatu yang mengerikan akan terjadi, sedang obsesif kompulsif adalah desakan untuk melakukan perilaku ritual dalam 
rangka mengurangi ketegangan yang dialami.

Kecemasan pada ibu bersalin bisa berdampak meningkatnya sekresi adrenalin. Salah satu efek adrenalin adalah konstriksi pembuluh darah sehingga suplai oksigen ke janin menurun. Penurunan aliran darah juga menyebabkan melemahnya kontraksi rahim dan berakibat memanjangnya proses persalinan. Tidak hanya sekresi adrenalin yang meningkat tetapi sekresi ACTH (Adrenocorticotropic hormone) juga meningkat, menyebabkan peningkatan kadar kortisol serum dan gula darah.

Kecemasan dapat timbul dari reaksi seseorang terhadap nyeri. Hal ini akan meningkatkan aktifitas saraf simpatik dan meningkatkan sekresi katekolamin. Sekresi katekolamin yang berlebihan akan menimbulkan penurunan aliran darah ke plasenta sehinga membatasi suplai oksigen serta penurunan efektifitas dari kontraksi uterus yang dapat memperlambat proses persalinan.

Efek dari kecemasan dalam persalinan dapat mengakibatkan kadar katekolamin yang berlebihan menyebabkan turunnya aliran darah ke rahim, turunnya kontraksi rahim, turunnya aliran darah ke plasenta, turunnya oksigen yang tersedia untuk janin serta dapat meningkatkan lamanya Persalinan. Hal ini juga dapat dimungkinkan adanya bayangan mengenai apa yang akan terjadi saat bersalin sehingga ibu merasa ketakutan karena sering mendengar cerita mengerikan tentang pengalaman saat melahirkan dan ini mempengaruhi ibu berfikiran proses persalinan yang menakutkan.

Hasil penelitian ini memiliki kesamaan dengan hasil penelitian oleh Rahmi (2013) dengan judul Hubungan Tingkat Kecemasan Dengan Kelancaran Proses Persalinan Ibu Primigravida di Rumah Sakit Ibu dan Anak Banda Aceh Tahun 2013 dengan hasil analisa bivariat didapatkan adanya hubungan antara tingkat kecemasan dengan kelancaran persalinan pada ibu primigravida dengan nilai $\mathrm{p}$ value: 0.00 . Penelitian oleh Anggriani (2006) dengan judul Pengaruh kecemasan ibu hamil terhadap lama persalinan di RSUD Mataram Nusa Tenggara Barat dengan hasil analisa bivariat diperoleh ada pengaruh yang signifikan lama persalinan terhadap tingkat kecemasan ibu bersalin dengan $p$ value: 0,013 .

Berdasarkan hal tersebut peneliti berasumsi bahwa tingkat kecemasan mempengaruhi lama persalinan kala II dikarenakan adanya ketakutan pada ibu akan rasa sakit psa saat proses persalinan sehingga ibu menjadi takut untuk mengedan sehingga lama persalinan akan menjadi lebih panjang. Oleh karena itu diharapkan tenaga kesehatan khususnya bidan berperan aktif dalam mengurangi tingkat kecemasan ibu selama proses persalinan karena berkaitan dengan gangguan pada proses persalinan dengan memberikan memberikan Asuhan Sayang Ibu yang meliputi memberikan rasa nyaman dan aman selama proses persalinan, menghargai kebiasaan budaya, praktik keagamaan dan kepercayaan dengan melibatkan ibu dan keluarga dalam pengambilan keputusan serta menjamin ibu dan keluarganya dengan memberitahu tentang apa yang terjadi dan apa yang bisa diharapkan.

\section{F. SIMPULAN DAN SARAN}

Berdasarkan hasil analisa data dan pembahasan, maka dapat diperoleh beberapa kesimpulan sebagai berikut: a. Tingkat kecemasan ibu bersalin sebagian besar dengan tingkat kecemasan sedang sebanyak 17 ibu (34\%).

b. Lama persalinan pada kala II ibu bersalin dengan lama persalinan kala II yang tidak normal sebanyak 22 ibu (44\%).

c. Ada ada hubungan antara tingkat kecemasan dengan lama persalinan kala II pada ibu bersalin dengan nilai $\mathrm{p}$ value: 0,009 .

Kemudian diharapkan tenaga kesehatan untuk berperan aktif dalam mengurangi tingkat kecemasan ibu selama proses persalinan karena berkaitan dengan gangguan pada proses persalinan dengan memberikan dukungan dan motivasi yang dapat mengurangi tingkat kecemasan ibu serta menganjurkan adanya pendamping selama proses persalinan ibu agar ibu dapat lebih tenang menjalani proses persalinan dengan memberikan Asuhan Sayang Ibu yang meliputi memberikan rasa nyaman dan aman selama proses persalinan, menghargai kebiasaan budaya, praktik keagamaan dan kepercayaan dengan melibatkan ibu dan keluarga dalam pengambilan keputusan serta menjamin ibu dan keluarganya dengan memberitahu tentang apa yang terjadi dan apa yang bisa diharapkan.

\section{DAFTAR RUJUKAN}

[1] Arikunto. Prosedur Penelitian Suatu Pendekatan Praktek. Jakarta: Rineka Cipta, 2010.

[2] Dinas Kesehatan Provinsi Lampung. Angka Kematian Ibu Di Lampung Tahun 2014.

[3] Hawari. Psikometri: Alat Ukur (Skala) Kesehatan Jiwa. Jakarta: Fakultas Kedokteran Universitas Indonesia, 2009.

[4] Hawari. Manajemen Stres, Cemas dan Depresi. Jakarta: Fakultas Kedokteran Universitas Indonesia, 2011.

[5] Jenny J.S. \& Sondakh. Asuhan Kebidanan Persalinan dan bayi Baru Lahir, Erlangga, Jakarta, 2013.

[6] JNPK-KR. Asuhan persalinan Normal dan Inisiasi menyusui Dini, Kemenkes, Jakarta, 2012.

[7] Manuaba. Ilmu kebidanan, Penyakit Kandungan, \& Keluarga Berencana untuk Pendidikan Bidan, EGC, Jakarta, 2010.

[8] Mochtar, R. Sinopsis Obstetri. Jakarta: Buku Kedokteran EGC, Jakarta, 2012.

[9] Notoadmojo. Metodologi Penelitian Kesehatan. Rineka Cipta, Jakarta, 2010.

[10] Prawirohardjo, S. Buku Acuan Nasional Pelayanan Kesehatan Maternal dan Neonatal. Yayasan Bina Pustaka Sarwono Prawirohardjo, Jakarta, 2010.

[11] Prawirohardjo, S. Ilmu Kebidanan. Yayasan Bina Pustaka Sarwono Prawirohardjo, Jakarta, 2010.

[12] Safaria \& Saputra. Manajemen Emosi. Bumi Aksara, Yogyakarta, 2009.

[13] Stuart, G. Buku Saku Keperawatan Jiwa Edisi 5. EGC, Jakarta, 2012.

[14] Sulistyawati, A. Asuhan Kebidanan Pada Masa Kehamilan. Salemba Medika, Jakarta, 2012.

[15] Yeyeh \& Lia. Asuhan Kebidanan Patologi. Transinfo Media, Jakarta, 2010. 